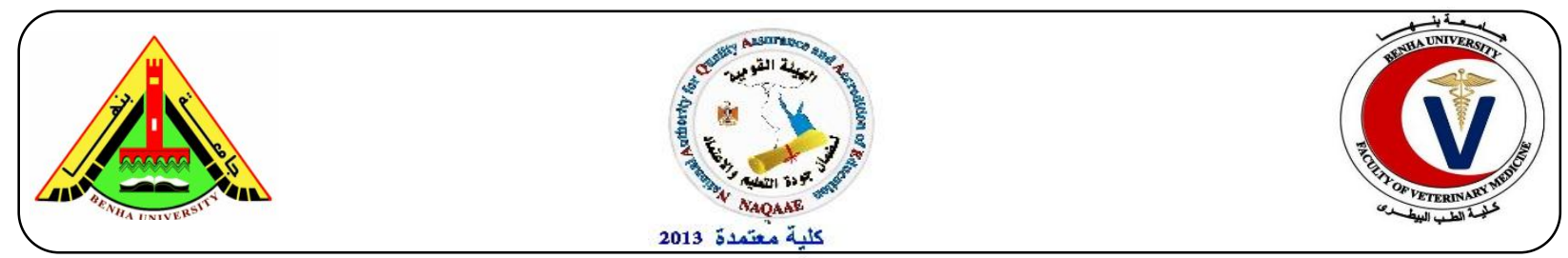

\title{
Incidence and toxigenic profile of Bacillus cereus in some fishes
}

\section{Hassanien, F.S. ${ }^{1}$; Hassan, M.A. ${ }^{1}$; El-Hariri, M.D. ${ }^{2}$, Eid Sayed ${ }^{*}{ }^{3}$}

${ }^{1}$ Food Hygiene Dep., Fac. Vet. Med., Benha Univ , ${ }^{2}$ Microbiology Dep., Fac. Vet. Med., Cairo Univ,

${ }^{3}$ Directorate of Veterinary Medicine, Giza.

Corresponding author E mail: agyad 2014@yahoo.com

\section{A B S T R A C T}

A total of 300 fish samples were collected from Giza and Cairo shops, supermarkets and restaurants. These samples were 150 raw fish samples of Tilapia, Mackerel and Sardine (50 for each) and 150 ready to eat fish samples of fried Tilapia, grilled Mackerel and grilled Sardine (50 for each). Each sample was subjected to bacteriological and molecular examination for detection of Bacillus cereus and its toxins. The obtained results using PCR indicated that the incidence of B. cereus in raw Tilapia, Mackerel and Sardine were 24\% (12/50) , 26\% (13/50) and 40\% (20/50) respectively ; while for hemolytic toxin was $75 \%(9 / 12), 62 \%(8 / 13)$ and $60 \%(12 / 20)$, non-hemolytic toxin was $25 \%$ $(3 / 12), 38 \%(5 / 13)$ and $40 \%(8 / 20)$, cytotoxin $\mathrm{K}$ was $16.5 \%(2 / 12), 15 \%(2 / 13)$ and 0 and Cereulide was $16.5 \%(2 / 12), 7.5 \%(1 / 13)$ and $5 \%(1 / 20)$ in positive samples of $B$. cereus in raw Tilapia, Mackerel and Sardine respectively. In ready to eat Tilapia, Mackerel and Sardine the incidence of $B$. cereus were $20 \%(10 / 50), 18 \%(9 / 50)$ and 30\% (15/50) respectively ; while for hemolytic toxin were $\vee \cdot \%(\vee /) \cdot), 67 \%(6 / 9)$ and $73 \%(11 / 15)$, non-hemolytic toxins were 30\% (3/10),33\% (3/9) and $27 \%$ (4/15) in in positive samples of $B$. cereus in ready to eat Tilapia, Mackerel and Sardine respectively. In this study we didn't detected any cytotoxin $\mathrm{K}$ or cereulide toxins genes in any of the ready to eat fish samples.

Keywords: Bacillus cereus, toxins, fish, ready to eat fish, PCR.

(BVMJ, 34 (1), 2018)

\section{INTRODUCTION}

Food and Agriculture Organization (1994) asserted that fish contributes about $60 \%$ of the world's supply of protein and that $60 \%$ of the developing world derives more than $30 \%$ of their annual protein from fish. Fish and ready to eat fish are susceptible to a wide variety of bacterial pathogens, most of which are capable of causing disease. Among these bacterial pathogens; Bacillus cereus, it is important duo to its ability to produce spores that survive in high temperature and grow at low temperatures (van Netten et al., 1990).

Bacillus cereus, a Gram-positive, rod shaped endospore-forming bacteria is an important cause of food-borne illness in humans and is frequently involved in foodborne outbreaks (Hall et al.,2001). The resistance of its spores to adverse environmental conditions has enabled it to 
get distributed widely in the environment. When food is not adequately refrigerated and in the absence of competitive flora, B. cereus grows well after cooking (Kramer and Gilbert ,1989).

B. cereus is frequently associated with diarrheal and emetic types of food borne illness. Out of two, diarrheal type syndrome caused by enterotoxin (s), results in diarrhea and the emetic type induces nausea and vomiting. B. cereus produces emetic toxin (Agata et al., 1995) and four other enterotoxins: hemolysin $\mathrm{BL}$ or $\mathrm{Hbl}$ (Beecher and Wong ,1994), nonhemolytic enterotoxin or Nhe (Lindback et al., 2004), Cytotoxin K or cytK (Lund et al.,2000) and enterotoxin FM or entFM (Asano et al., 1997).

The aim of the present investigation was to study the incidence and level of contamination with $\mathrm{B}$. cereus in fish and ready to eat fish using polymerase chain reaction (PCR) besides detection of toxins gene profile of isolates to determine their pathogenic nature.

\section{MATERIAL AND METHODS}

\subsection{Collection of the samples:}

A total of 300 fish samples were collected from Giza and Cairo shops, supermarkets and restaurants. These samples were 150 raw fish samples of Tilapia, Mackerel and Sardine (50 for each) and 150 ready to eat fish samples of fried Tilapia, grilled Mackerel and grilled Sardine (50 for each). Each sample was subjected to bacteriological and molecular examination for detection of Bacillus cereus and its toxins.
2.2. Isolation and identification of $B$. cereus:

It was carried out according to (Hwang and Park, 2015) and (Harrigan and McCane , 1976) .

\subsection{DNA template preparation:}

One typical colony from each of the isolates was picked up and inoculated in 5 $\mathrm{ml}$ of Brain Heart Infusion (BHI) broth and incubated overnight at $35{ }^{\circ} \mathrm{C}$. The broth culture was subjected for DNA extraction using QIA amp DNA mini kit as per the instructions of manufacturer.

\subsection{Molecular characterization of $B$.} cereus and its toxins:

The primers used for the detection of toxin genes ( $h b l$, nhe, cytK and ces) in the current study are described by (EhlingSchulz et al.,2006) (Table 1).

The PCR amplification mixture (20 $\mu \mathrm{l})$ which was used for the detection included $2 x$ master mix, $5 \mu$ of template DNA, $1 \mu \mathrm{l}$ for forward and reverse of each oligonucleotide primers. The volume was completed by sterile free water to $20 \mu \mathrm{l}$, and the vortex was used to mix them well.

The cycling conditions for PCR for detection of B.cereus toxins genes were : initial denaturation at $94^{\circ} \mathrm{C}$ for $2 \mathrm{~min}$, followed by 35 cycles of denaturation step at $94^{\circ} \mathrm{C}$ for $15 \mathrm{~min}$, annealing step at $60^{\circ} \mathrm{C}$ for $45 \mathrm{~min}$, extension step at $72^{\circ} \mathrm{C}$ for 2 min, and final extension step at $72^{\circ} \mathrm{C}$ for 5 min. PCR products were detected in $1.5 \%$ agarose gel stained with ethidium bromide, viewed by U.V. light. 
Table (1): Oligonucleotide primers sequences of toxins genes in Bacillus cereus strains: Source (Ehling-Schulz et al., 2006) Metabion (Germany):

\begin{tabular}{ccc}
\hline Gene & Primer Sequence (5'-3') & $\begin{array}{c}\text { Amplified } \\
\text { product }\end{array}$ \\
\hline \multirow{2}{*}{$h b l$} & HD2 F (GTA AAT TAI GAT GAI CAA TTTC) & $1091 \mathrm{bp}$ \\
\multirow{2}{*}{ Nhe } & HA4 R (AGA ATA GGC ATT CAT AGA TT) & \\
& NA2 F (AAG CIG CTC TTC GIA TTC) & $766 \mathrm{bp}$ \\
& NB1 R (ITI GTT GAA ATA AGC TGT GG) & \\
& CK F (ACA GAT ATC GGI CAA AAT GC) & \multirow{2}{*}{$421 \mathrm{bp}$} \\
\multirow{2}{*}{ Ces } & CK R (CAA GTI ACT TGA CCI GTT GC) & \multirow{2}{*}{$1271 \mathrm{bp}$} \\
& Ces F (GGTGACACATTATCATATAAGGTG) \\
\hline
\end{tabular}

\section{RESULTS}

Table (2) revealed that by using PCR for detection of Bacillus cereus and its toxins genes in raw samples of Tilapia, Mackerel and Sardine. The percentage of positive samples for B. cereus were $24 \%$ (12/50), 26\% (13/50) and 40\% (20/50) respectively while for hemolytic, nonhemolytic toxins, cytotoxin $\mathrm{K}$ and Cereulide toxins in positive samples of $B$. cereus were $75 \%(9 / 12), 62 \%(8 / 13)$ and $60 \%(12 / 20)-25 \%(3 / 12), 38 \%(5 / 13)$ and $40 \%(8 / 20)-16.5 \% \quad(2 / 12), \quad 15 \%$ $(2 / 13)$ and $0-16.5 \%(2 / 12), 7.5 \%(1 / 13)$ and 5\% (1/20) in Tilapia- Mackerel Sardine respectively.
Table (3) showed that detection of Bacillus cereus and its toxins genes in ready to eat samples of fried Tilapia, grilled Mackerel and grilled Sardine. The percentage of positive samples for $B$. cereus were $20 \%$ (10/50), 18\% (9/50) and $30 \% \quad(15 / 50)$ respectively while for hemolytic, non-hemolytic toxins in positive samples of B. cereus were $70 \%$ (7/10),67\% (6/9) and 73\% (11/15) - 30\% (3/10), 33\% (3/9) and $27 \%(4 / 15)$ in fried Tilapia - grilled Mackerel - grilled Sardine respectively. In this study we didn't detected any cytotoxin $\mathrm{K}$ or cereulide toxins genes in any of the ready to eat fish samples.

Table (2) incidence of Bacillus Cereus and its toxins genes in raw fish by using PCR:

\begin{tabular}{ccccc}
\hline & Tilapia & Mackerel & Sardine & p-value \\
\hline No. of Samples & 50 & 50 & 50 & \\
Bacillus cereus & $12(24 \%)$ & $13(26 \%)$ & $20(40 \%)$ & 0.203 \\
$*$ hbl & $9(75 \%)$ & $8(62 \%)$ & $12(60 \%)$ & 0.658 \\
$*$ nhe & $3(25 \%)$ & $5(38 \%)$ & $8(40 \%)$ & 0.312 \\
$*$ Cyt K & $2(16.5 \%)$ & $2(15 \%)$ & 0 & 0.547 \\
*Ces & $2(16.5 \%)$ & $1(7.5 \%)$ & $1(5 \%)$ & 1.000 \\
\hline
\end{tabular}

* $h b l$ hemolysin BL, nhe non-hemolytic enterotoxin, Cyt $K$ cytotoxin $\mathrm{K}$, Ces cereulide, 
Table (3) incidence of Bacillus Cereus and its toxins genes in ready to eat fish by using PCR:

\begin{tabular}{ccccc}
\hline & $\begin{array}{c}\text { Tilapia } \\
\text { (fried) }\end{array}$ & $\begin{array}{c}\text { Mackerel } \\
\text { (grilled) }\end{array}$ & $\begin{array}{c}\text { Sardine } \\
\text { (grilled) }\end{array}$ & P. value \\
\hline No. of Samples & 50 & 50 & 50 & \\
Bacillus Cereus & $10(20 \%)$ & $9(18 \%)$ & $15(30 \%)$ & 0.330 \\
hbl & $7(70 \%)$ & $6(67 \%)$ & $11(73 \%)$ & 0.461 \\
nhe & $3(30 \%)$ & $3(33 \%)$ & $4(27 \%)$ & 1.000 \\
Cyt K & 0 & 0 & 0 & \\
Ces & 0 & 0 & 0 & \\
\hline
\end{tabular}



Photo (1) Agarose gel electrophoresis of PCR for detection of $h b l$ gene of $B$. cereus. (1091-bp fragment) in examined samples. Marker (Gel Pilot 100 bp. ladder). Lane1, negative control for Bacillus cereus. (Master Mix without any DNA). Lane 2 to 6: positive results for $h b l$ toxin gene of B. cerus. 
Incidence and toxigenic profile of Bacillus cereus in some fish

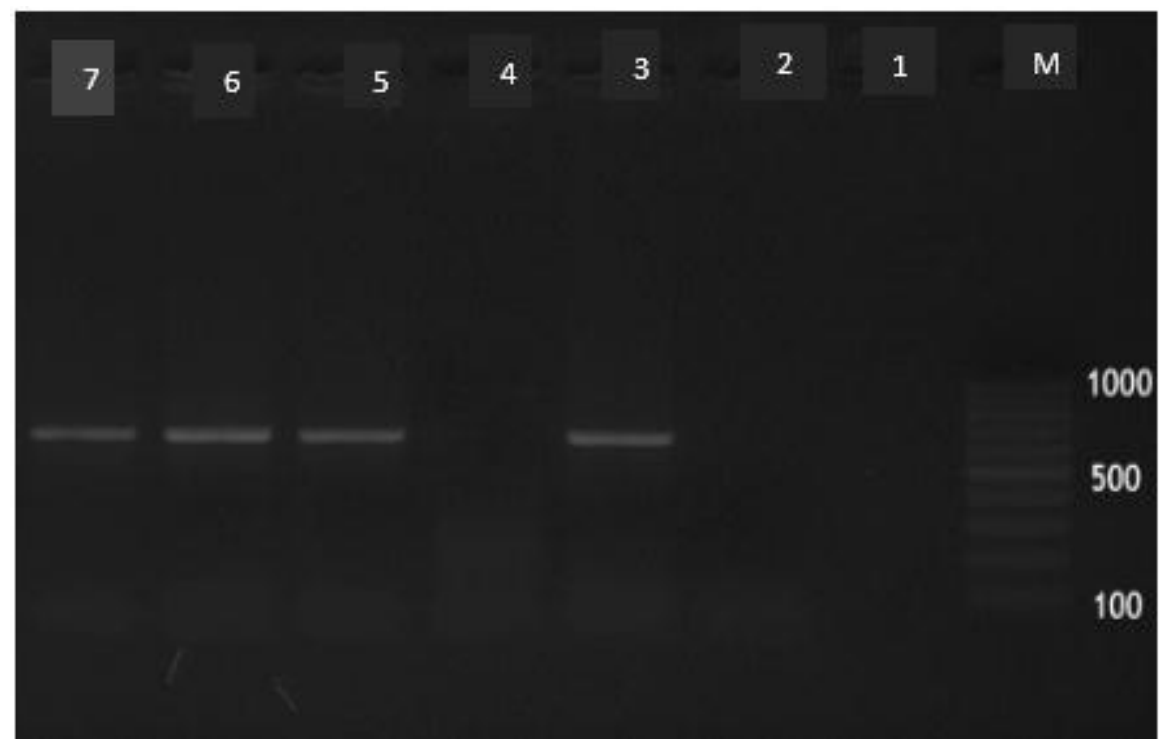

Photo (2) Agarose gel electrophoresis of PCR for detection of nhe gene of B. cereus. (766-bp fragment) in examined samples.Marker (Gel Pilot 100 bp. ladder).Lane1, negative control for Bacillus cereus. (Master Mix without any DNA). Lane 2 and 4: negative results for $B$. cerus toxins. Lane3, 5,6 7: positive results for nhe toxin gene of $B$. cerus.

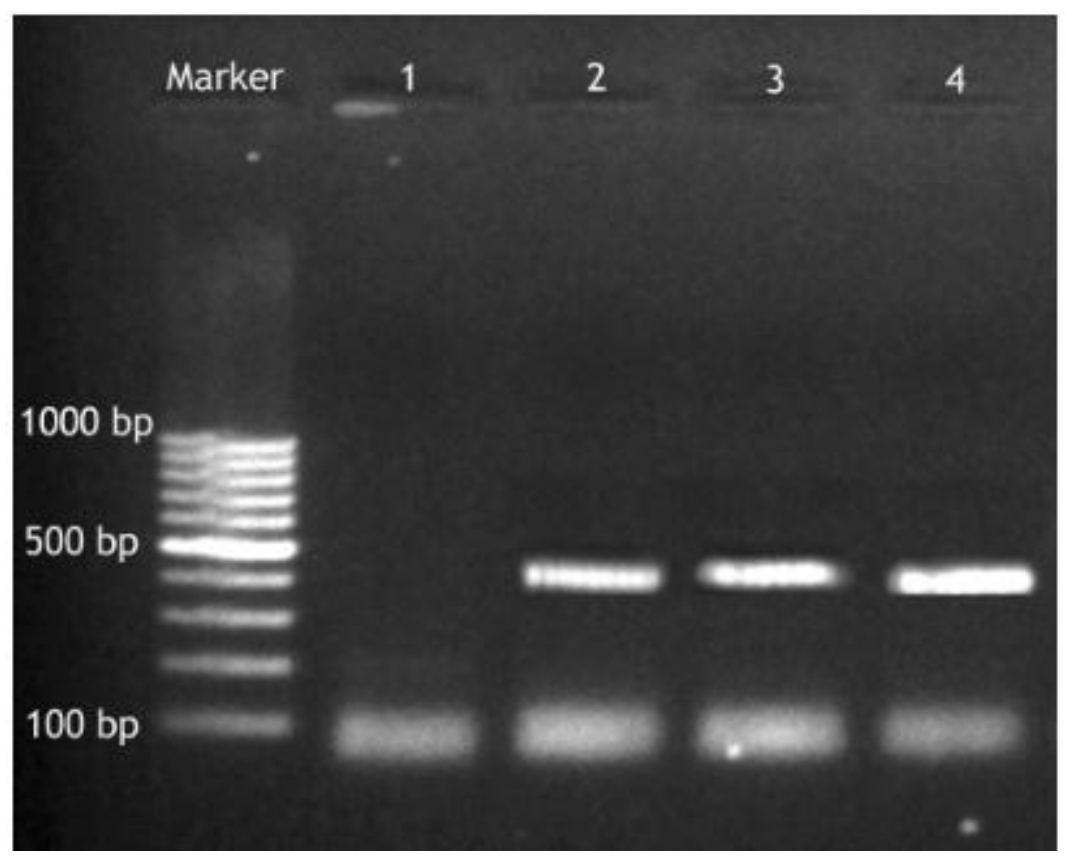

Photo (3) Agarose gel electrophoresis of PCR for detection of $c y t K$ gene for B. cereus. (421-bp fragment) in examined samples.

Marker (Gel Pilot $100 \mathrm{bp}$. ladder). Lane1, negative control for Bacillus cereus. (Master Mix without any DNA). Lane 2 to 4: positive results for $c y t K$ toxin gene of $B$. cerus. 


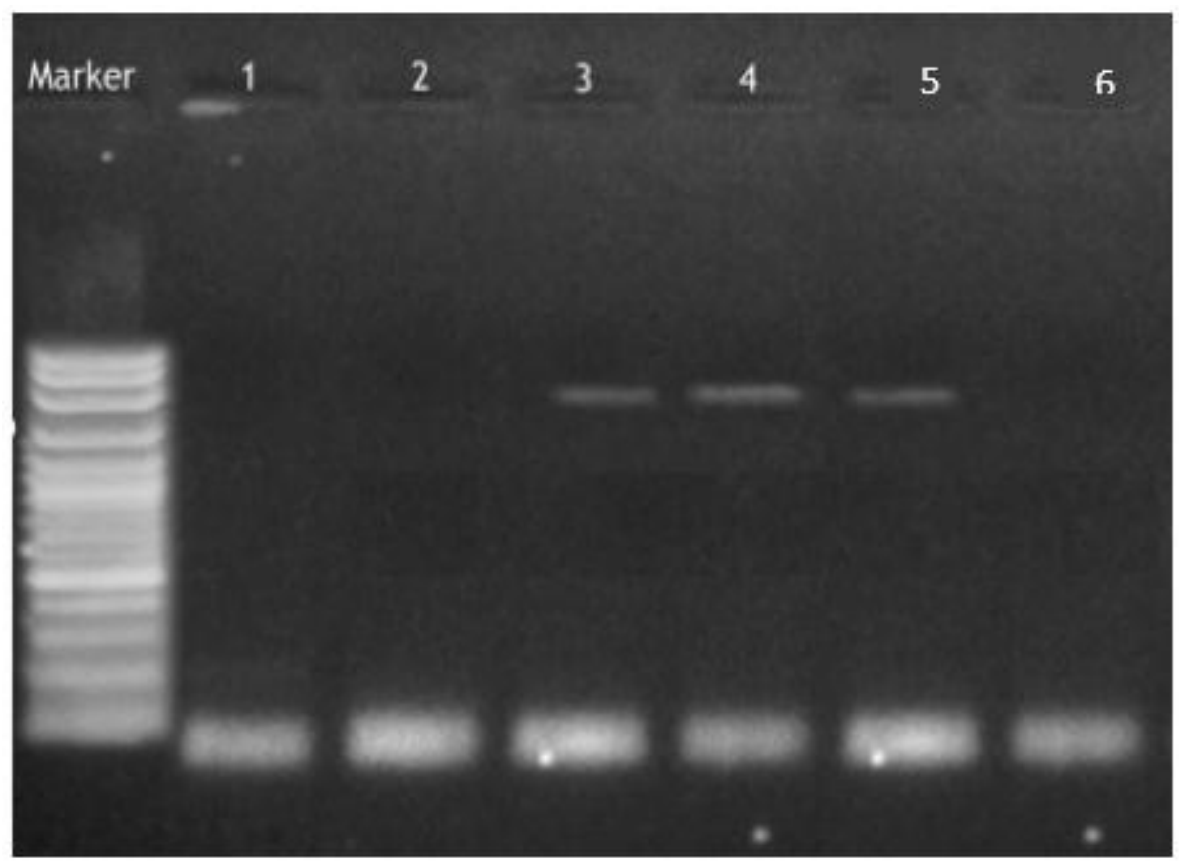

Photo (4) Agarose gel electrophoresis of PCR for detection of ces gene for B. cereus. (1271 fragment) in examined samples.

Marker (Gel Pilot 100 bp. ladder). Lane1, negative control for Bacillus cereus. (Master Mix without any DNA). Lane 2 and 6: negative results for $B$. cerus toxines. Lane 3 to 5: positive results for ces toxin gene of $B$. cereus

\section{DISCUSSION}

Fish is very important for human nutrition because it is rich in animal protein and other elements for the maintenance of healthy body (Andrew, 2001). Raw or cooked fish may be harbored $B$. cereus which can cause human illness duo to it characterized by spore formation and can produce two types of toxin; diarrheic and emetic toxins.

Results in Table (2) agree with (AbdElaziz,2016) who reported that the Positive $B$. cereus isolates in raw meat, minced meat and meat luncheon were $15 \%$ (3 / 20), 20\% (4 / 20) and 20\% (4 / 20) respectively while hemolytic and non-hemolytic toxins among the positive isolate were $33 \%(1 / 3)$ and $100 \%(3 / 3), 44 \%(1 / 4)$ and $100 \%(4 / 4)$ and $50 \%(2 / 4)$ and $100 \%$ (4/4) in raw meat, minced meat and meat luncheon respectively.

Also, the result agrees with (Abbas $e t$ al., 2014) who detect the presence of hemolytic ( $h b l A, h b l C$ and $h b l D$ ) and nonhemolytic enterotoxin (nheA, nheB and nheC) genes in Bacillus cereus strains isolated from milk and milk product collected from local markets. they revealed that the percentage of these genes in $B$. cereus isolates were 22.58, 51.61, 9.67, $90.32,58.06$ and $54.83 \%$, respectively. The result agreed with (Tewari et al., 2015) who isolated B. cereus from $30.9 \%$ (29) of the 94 raw meat and meat products samples and 
its toxin genes $n h e, h b l$ and cyt $\mathrm{K}$ were isolated from $89.7 \%$ (26), $55.2 \%$ (16) and $41.4 \%$ (12), respectively. And also agree with (Ehling-Schulz et al., 2006) who detected $n h e, h b l$, cytK and ces toxins genes from B.cereus food isolates and clinical isolates.

The result is low than that of (Rather, 2011) who detected the incidences of various enteroxigenic genes of Bacillus cereus in meat and meat products by PCR and the result of hblD, hblA, hblC, nheA, nheB, nheC, cytK and entFM were $66.10 \%$, $66.10 \%, 67.78 \%, 96.61 \%, 96.61 \%, 93.22 \%$, $67.78 \%$ and $100 \%$, respectively. Also, the result is low than that detected by (Khudor et al., 2012) who make Screening of $B$. cereus isolates from milk, soft cheese, curls cheese and yogurt by polymerase chain reaction (PCR) and revealed the presence of diarrheal toxin $c y t K$ gene in $87.09 \%$ of isolates.

The low result of the emetic toxin (cereulide) in our study agree with the result of (Abbas et al., 2012) who detected the emetic gene in a percentage of $0.00 \%$, $10.00 \%$, and $20.00 \%$ in milk, yogurt and curls cheese, respectively.

In relation of presence of $B$. cereus in raw fish the result agrees with result obtained by (Prasad, 2014) who recovered $B$. cereus from shark, anchovy, ribbion fish, sole, mackerel, seer, tuna, snapper, sardine, and pomfret commercially available in Bangalore region- India by using PCR and with (Das et al., 2009) who detect $B$. cereus and enterotoxigenic $B$. cereus in fish samples by PCR in a percentage of $36.7 \%$ and $29.41 \%$ respectively also they interpreted that all the diarrheal enterotoxin producing isolates showed the presence of hbla gene, but hbla gene was not present in any of the nonenterotoxigenic isolates.i.e; hbla gene specific PCR can be employed for differentiation of enterotoxigenic B. cereus isolates from non-enterotoxigenic isolates. And agree with (Rahmati And. Labbe, 2008) who reported that in 347 fresh and processed retail seafood samples (including Mackerel. Tilapia, Salmon, Trout, Carp and fish past) Sixty-two samples contained $B$. cereus and Thirty (48\%) of 62 isolates produced both the hemolysin BL (HBL) and nonhemolytic (NHE) enterotoxins, and 58 (94\%) and 31 (50\%) produced NHE or HBL toxins, respectively.

Counts ranging from 200 to $10^{9} \mathrm{gm}^{-1}$ $\left(\right.$ or $\left.\mathrm{ml}^{-1}\right)$ B. cereus have been reported in the incriminated foods after food poisoning, giving total infective doses ranging from about $5 \times 10^{4}$ to $10^{11}$ partly due to the large differences in the amount of enterotoxins produced by different strains, the total infective dose vary between $10^{5}$ and $10^{8}$ viable cells or spores. So, any food containing more than $10^{3}$ B. cereus $/ \mathrm{g}^{-1}$ cannot considered completely safe for consumption (Granum and Lund, 1997).

Result in Table (3) agree with that recorded by (Jawad, 2016) who detected 35 B. cereus isolates from 70 ready to eat cooked rice samples and it was found that in the $35 \mathrm{~B}$. cereus isolates $4(11 \%)$ isolates positive towards $h b l B$ and $12(34 \%)$ isolates positive towards nheA by using PCR. The result disagree with (El- Sayed ,2015) who isolate B.cereus from samples of meat sandwiches of kofta, fried liver (kibda) and 
shawerma in a percentage of $94.29,88.57$ and 97.14 , respectively. In addition that he didn't record $h b l$ gene of $B$. cereus in any of examined samples but record (nhe,cytk and ces) genes in all examined samples.

Generally, the infection of raw fish with Bacillus cereus and its toxins is higher than the infection in ready to eat fish. This my duo to the fact that the cooking process may effect on the count of aerobic spore forming bacteria, its ability to form active spore or toxins. (Parry and Gilbert, 1980), (Houška et al., 2007) and (Desai and Varadaraj, 2010).

The low percentage of cereulide detected in raw fish and its absence in ready to eat fish may be due to the fact that The emetic toxin only seems to be produced when Bacillus cereus is grown on particular substrates particularly rice and other farinaceous materials. Fried or cooked rice has been implicated in nearly $95 \%$ of all emetic toxin food poisoning outbreaks (Jenson and Moir, 1997). Also, these results may be attributed to that the emetic toxin titers were much highest when $B$. cereus was grown in skim milk, cooked rice suspension and minimum amino acid-defined medium (MADM) than growth in brain heart infusion (BHI) broth, trypto-soya broth, nutrient broth, tryptosoya agar and cooked rice agar (Agata et al., 1999) and (Shinagawa et al., 1992).

Finally, it can be concluded that, it is important to make strict hygienic measures in handling and preparation of fish from fishing to consumption to avoid contamination with Bacillus cereus and its toxins.

\section{REFERENCES}

Abbas, B.A; Khudor, M.H.; Saeed, B.M.S. 2012. Molecular detection of Bacillus cereus emetic toxin gene by PCR and determine its susceptibility against punica granatum extracts. Basrah journal of veterinary research, vol. 11, 4, (79-94).

Abbas, B.A.; Khudor, M.H.; Saeed, B.M.S 2014. Detection of $h b l$, nhe and bceT Toxin Genes in Bacillus cereus Isolates by Multiplex PCR. Int. J. Curr. Microbiol. App. Sci., 3(11) 1009-1016.

Abd-Elaziz, M.H.G. 2016. Bacteriological and molecular studies on Bacillus cereus isolated from meat and meat products. Ph.D. Thesis. microbiology dep. Veterinary medicine, Cairo university.

Agata, N.; Ohta, M.; Arakawa, Y.; Mori, M. 1995. The bceT gene of Bacillus cereus encodes an enterotoxic protein. Microbiology 141:983-988.

Agata, N., Ohta, M., Mori, M.; Shibayama, K. 1999. Growth conditions of and emetic toxin production by Bacillus cereus in a defined medium with amino acids. Microbiology and Immunology, 43: 15-18

Andrew, A.E. 2001. Fish processing Technology. University of Ilorin press, Nigeria, pp: 7-8.

Asano, S.I.; Nukumizu, Y.; Bo, H.; Iizuka, T.; Yamamoto, T. 1997. Cloning of novel enterotoxin genes from Bacillus cereu Bacillus thuringiensis. Appl. Environ. Microbiol., 63:1054-1057. 
Beecher, D.J; Wong, A.C.L. 1994. Improved purification and characterization of hemolysin BL, a haemolytic dermonecrotic vascular permeability factor from Bacillus cereus. Infect. Immun., 62:980-986.

Das et al. (2009) found that B. cereus and enterotoxigenic B. cereus were found to be in 36.7 and 29.41 per cent of examined fish samples, respectively. All the diarrheal enterotoxin producing isolates showed the presence of hbla gene, but hbla gene was not present in any of the non-enterotoxigenic isolates.

Desai, S.V.; Varadaraj, M.C. 2010. Behavioural pattern of vegetative cells and spores of Bacillus cereus as affected by time-temperature combinations used in processing of Indian traditional foods. J Food Sci Technol., 47(5):549-556.

Ehling-Schulz, M.; Gmnebretiere, M.I.I.; Montlian, A.; Berge, O.; Fricker, M.; Svensson, B. 2006. Toxin gene profiling of enterotoxic and emetic Bacillus cereus. FEMS Microbiol.. Lett., 260:.232-240.

El-Sayed, A.A. 2015. Probable dangers from take away meat products meals. Ph. D. thesis. Food Control Dep. Vet. Medicine, Zagazig University.

Food and Agriculture Organization of the United Nations, 1994. Review of the State of the World Fishery Resources; Marine Fisheries. FAO Fishery Circular No 920. Rome.
Granum, P.E.; Lund, T. 1997. Bacillus cereus and its food poisoning toxins. FEMS Microbiol. Lett., 157: 223-228.

Hall, J.A.; Goulding, J.S.; Bean, N.H.; Tauxe, R.V.; Hedberg, C.W. 2001. Epidemiologic profiling: evaluating foodborne outbreaks for which no pathogen was isolated by routine laboratory testing: United States, 198289. Epidemiol Infect 127:381-387.

Harrigan, W.F.; Mccance, M.C. 1976. Laboratory methods in food and Dairy Microbiology. Academic press, New York, San Francisco.

Houška, M., Kýhos, K., Landfeld, A., Průchová, J., Schlemmerová, L., Šmuhařová, H., Špelina, V., Novotná, P. 2007. Dry heat inactivation of Bacillus cereus in rice. Czech J. Food Sci., 25: 208-213.

Hwang, J.Y.; Park, J.H. 2015. Characteristics of enterotoxin distribution, hemolysis, lecithinase, and starch hydrolysis of Bacillus cereus isolated from infant formulas and ready-to-eat foods. Department of Food Science and Biotechnology, Gachon University, Sungnam 461-701, republic of Korea. J. Dairy Sci., 98:1-9.

Jawad, N. 2016. Determination of Haemolytic and Nonhaemolytic Genes Profiles of Bacillus cereus Strains Isolated from fried Rice samples by Polymerase Chain Reaction (PCR) technique. International Journal of ChemTech Research, 9(11), pp. 151156. 
Jenson, I; Moir, C.J. 1997. Bacillus cereus and other Bacillus species, In A. D. Hocking, G. Arnold, I. Jenson, K. Newton, and P. Sutherland (ed.), Foodborne Microorganisms of Public Health Significance, 5th ed. Australian Institute of Food Science and Technology Inc., NSW Branch, Food Microbiology Group, Sydney, New South Wales, Australia. pp. 379-406.

Khudor, M.H.; Abbas, B.A.; Saeed, B.M.S. 2012. Molecular detection of enterotoxin (cytk) gene and antimicrobial susceptibility of bacillus cereus isolates from milk and milk products. Bas. J. Vet. Res., Vol.11, No.1. p.: 164-173

Kramer, J.M.; Gilbert, R.J. 1989. Bacillus cereus and other Bacillus species, P. 21-70. In Dayle, M.P. (ed) Food borne Bacterial pathogens, Marcel Dekkar, New York.

Lindback, T.; Fagerlund, A.; Rodland, M.S.; Granum, P.E. 2004. Characterization of the Bacillus cereus Nhe enterotoxin. Microbiology, 150: 3959-3967.

Lund,T.; Debuyser, M.L.; Granum, P.E. 2000. A new cytotoxin from Bacillus cereus that may cause necrotic enteritis. Mol. Microbiol., 38:254-261.

Parry, J.M.; Gilbert, R.J. 1980. Studies on the heat resistance of Bacillus cereus spores and growth of the organism in boiled rice. J. Hyg., Camb. 84, 77.
Prasad, M.P. 2014. Molecular characterization of Enterotoxigenic Bacillus cereus species isolated from tropical marine fishes using RAPD markers. Int. J. Pure App. Biosci. 2 (4): 189-195.

Rahmati, T.; Labbe, R. 2008. Levels and toxigenicity of Bacillus cereus and Clostridium perfringens from retail seafood. J. Food Prot. 71, 1178-1185.

Rather, M.A.; Aulakh, R.S.; Gill, J.P.S.; Rao, T.S.; Hassan, M.N. 2011. Direct Detection of Bacillus cereus and its Enterotoxigenic Genes in Meat and Meat Products by Polymerase Chain Reaction. Journal of Advanced Veterinary Research Volume 1, 99104.

Shinagawa, K., Otake, S., Matsusaka, N.; Sugii, S. 1992. Production of the vacuolation factor of Bacillus cereus isolated from vomiting-type food poisoning. J. Vet Med Sci 54: 443-6

Tewari, A.; Singh, S.P; Singh, R. 2015. Incidence and enterotoxigenic profile of Bacillus cereus in meat and meat products of Uttarakhand, India. J Food Sci Technol., 52(3):1796-1801.

Van Netten, P.; Van De Noosdijik, A.; Van Hoensel, P.; Mossel, D.A.A.; Perales, J. 1990. Psyehrotrophic strains of Bacillus cereus producing enterotoxin. J. Appl. Bacteriol., 69:73- 79. 